DOI 10.31558/2307-2318.2020.1.12

УДК: 005.334.2:005.5334.716(477.64)

Романець I. В., аспірант Запорізького національного університету

Маркова С.В., канд. екон. наук, доцент кафедри бізнес-адміністрування і менеджменту зовнішньоекономічної діяльності Запорізького національного університету

Головань О.О., канд. фіз.-мат. наук, доцент кафедри бізнес-адміністрування i менеджменту зовнішньоекономічної діяльності Запорізького національного університету

\title{
ОСОБЛИВОСТІ УПРАВЛІННЯ КОНФЛІКТАМИ НА КП НВК «ІСКРА»
}

У статті проаналізовано діяльність та структуру персоналу промислового підприємства. Визначено, що конфлікт має негативний характер, вплив якого зменшує ефективність роботи та продуктивність праці персоналу. Детально вивчені проблеми управління конфліктами в колективі КП НВК «Іскра»; встановлено, що управління конфліктом неможливе без виявлення причини та наслідків його виникнення. Запропоновано рекомендації щодо профілактики конфліктних ситуацій та управління конфліктами в колективі підприємства. У дослідженні використано методику діагностики схильності особистості до конфліктної поведінки К. Томаса на прикладі роботи відділу кадрів КП НВК «Іскра», згідної якої було визначено, що результативна взаємодія команди не можлива без управління конфліктами виникнення, яких потрібно виключити або звести до мінімуму.

Ключові слова: конфлікт, управління конфліктом, колектив, промислове підприємство.

Рис. - 3. Табл. - 2 Літ. - 6

Романец И.В., Маркова С.В., Головань О.А.

ОСОБЕННОСТИ УПРАВЛЕНИЯ КОНФЛИКТАМИ НА КП НПК «ИСКРА»

В статье анализируется деятельность и структура персонала промышленного предприятия. Установлено, что конфликт имеет негативный характер, воздействие которого снижает эффективность и производительность персонала. Проблемы урегулирования конфликтов в коллективе КП НПК «Искра» детально изучены, установлено, что контроль над конфликтом невозможен без раскрытия причин и последствий его возникновения. Предлагаются рекомендации по предотвращению конфликтных ситуаций и урегулированию конфликтов в коллективе предприятия. В статье методику диагностики склонности личности к конфликтному поведению К. Томаса апробировано на примере отдела кадров КП НПК «Искра»; установлено, что эффективное взаимодействие команды невозможно без контрольных конфликтов, возникновение которые должно быть исключено или сведено к минимуму.

Ключевые слова: конфликт, управление конфликтом, коллектив, промышленное предприятие.

\section{Romanets Y., Markova S., Holovan O.}

FEATURES OF CONFLICT MANAGEMENT KP SPC «ISKRA»

The article analyses activity and structure of industrial enterprise personnel. It is determined that the conflict has a negative nature whose impact reduces the efficiency and productivity of staff. The problems of conflicts management in the collective KP SPC «Iskra» are studied in detail, it is established that the control of the conflict is impossible without revealing the cause and consequences of its occurrence. Recommendations on the prevention of conflict situations and management of the conflicts in the group of enterprises are proposed. 
In the article, the methodology of propensity of personality diagnostics was applied to $\mathrm{K}$. Thomas's conflict behaviour on the example of HR department KP SPC «Iskra», which was determined that the effective interaction of the team is not possible without the control conflicts occurrence, which should be excluded or minimized.

Keywords: conflict, the management of the conflict, collective, industrial enterprise.

Постановка проблеми. Існування складних політичних, економічних та соціально-культурних умов при функціонуванні українських підприємств $\epsilon$ не можливими без конфліктних ситуацій. Конфлікт - це «зіткнення» або «боротьба», вороже відношення (у перекладі з латини); відсутність згоди; ситуація, в якій кожна із сторін прагне зайняти позицію, несумісну і протилежну по відношенню до інтересів іншої сторони [1]. Зрозуміло, що існування такої ситуації на підприємстві створює негативні передумови щодо формування сприятливого іміджу, втрат ефективного робочого часу, зменшення продуктивності та інноваційної спрямованості діяльності персоналу. Отже, конфлікт - ситуація, яку потрібно уникати та попереджувати.

Аналіз останніх досліджень і публікацій. Теоретичну основу дослідження складають праці А. Дмітрієва, М. Логунова, М. Пірен [2], А. Пойченко, Скотт Г. Джинні, які досліджують питання управління конфліктами на підприємствах.

Постановка завдання. Метою статті є створення умов для продуктивної роботи персоналу за рахунок зменшення конфліктних ситуацій на підприємстві.

Для досягнення мети було поставлено наступні завдання:

аналіз вікової, статевої структури персоналу на промисловому підприємстві як каналів отримання оперативної інформації щодо передумов та можливостей для виникнення можливих конфліктних ситуацій;

дослідження сучасних трендів та технологій в сучасному управлінні конфліктами; узагальнення пропозицій щодо розробки ефективної системи попередження конфлікту на підприємстві.

Виклад основного матеріалу дослідження. Казенне підприємство «Наукововиробничий комплекс «Іскра» (КП НВК «Іскра») - один із провідних розробників та виробників наземної радіолокаційної техніки оборонного комплексу України. Відноситься до Міністерства промислової політики України. Входить в список підприємств України, що мають стратегічне значення для економіки та безпеки держави [3]. Продукція НВК «Іскра» користується попитом як на вітчизняному, так і на закордонних ринках військової техніки. 3 маркою «Іскра» вироблено більше 6000 високоефективних, надійних і простих в експлуатації радіолокаційних станцій, які продовжують працювати більш ніж в 50 країнах світу. Особовий склад підприємства налічує 3109 осіб. 3 них 2682 мають вищу освіту, 473-вчені звання, 18 осіб нагороджено державними нагородами України, 210 - відомчими нагородами оборони України, 13 осіб мають почесне звання заслужений діяч науки і техніки (рис. 1).

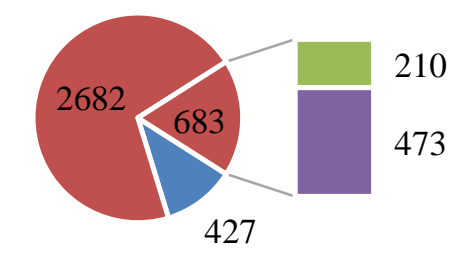

- Середня освіта - Вища освіта $\quad$ Відомчі нагороди " Вчені звання

Рисунок 1 - Структура працівників КП НВК «Іскра» за освітою 
Таблиця 1

Загальна кількість робітників КП «НВК «Іскра», осіб 2016-2018 рр.

\begin{tabular}{|c|c|c|c|c|c|}
\hline \multirow{2}{*}{ № } & \multirow{2}{*}{\multicolumn{2}{|c|}{ Показники }} & \multicolumn{3}{|c|}{ Роки } \\
\hline & & & 2016 & 2017 & 2018 \\
\hline 1 & $\begin{array}{r}\text { Загаль } \\
\text { спів }\end{array}$ & $\begin{array}{l}\text { Іькість } \\
\text { ників }\end{array}$ & 3584 & 3841 & 3109 \\
\hline 2 & \multirow{2}{*}{ Стать } & Жін. & 1498 & 1964 & 1625 \\
\hline 3 & & Чол. & 2086 & 1877 & 1484 \\
\hline 4 & \multirow{4}{*}{ За віком } & $18-34 p$. & 518 & 682 & 846 \\
\hline 5 & & 35-54p. & 1086 & 1206 & 1354 \\
\hline 6 & & $55-59 \mathrm{p}$. & 1147 & 1338 & 727 \\
\hline 7 & & більше 60p. & 833 & 615 & 172 \\
\hline 8 & \multirow{2}{*}{ За освітою } & вища & 1896 & 2173 & 2682 \\
\hline 9 & & н/вища & 1688 & 1668 & 427 \\
\hline
\end{tabular}

Згідно таблиці 1, КП НВК «Іскра» налічується 3109 співробітників, 3 них 1625 жінок та 1484 чоловіка (рис. 2).

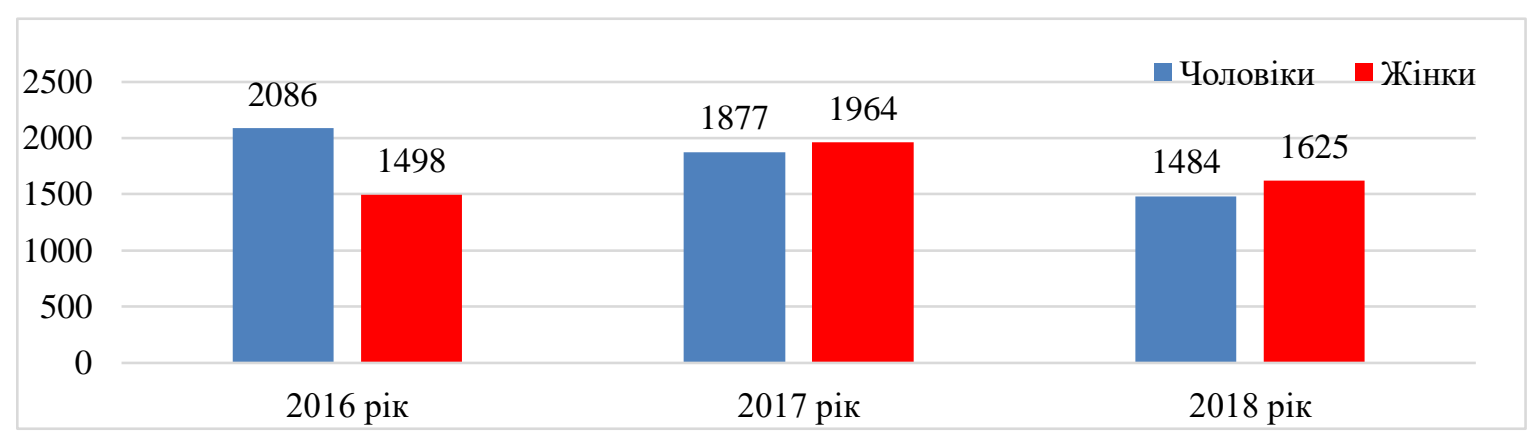

Рисунок 2 - Співвідношення працівників КП НВК «Іскра», за статтю у 2016-2018 p.

Простежується, що переважає жіноча стать, у процентному співвідношенні виглядає так: 2016p. - 41,7\%; 2017p.-51,1\%; 2018p.-52,2\%. Також спостерігається поступове зменшення загальної кількості співробітників (рис. 3).

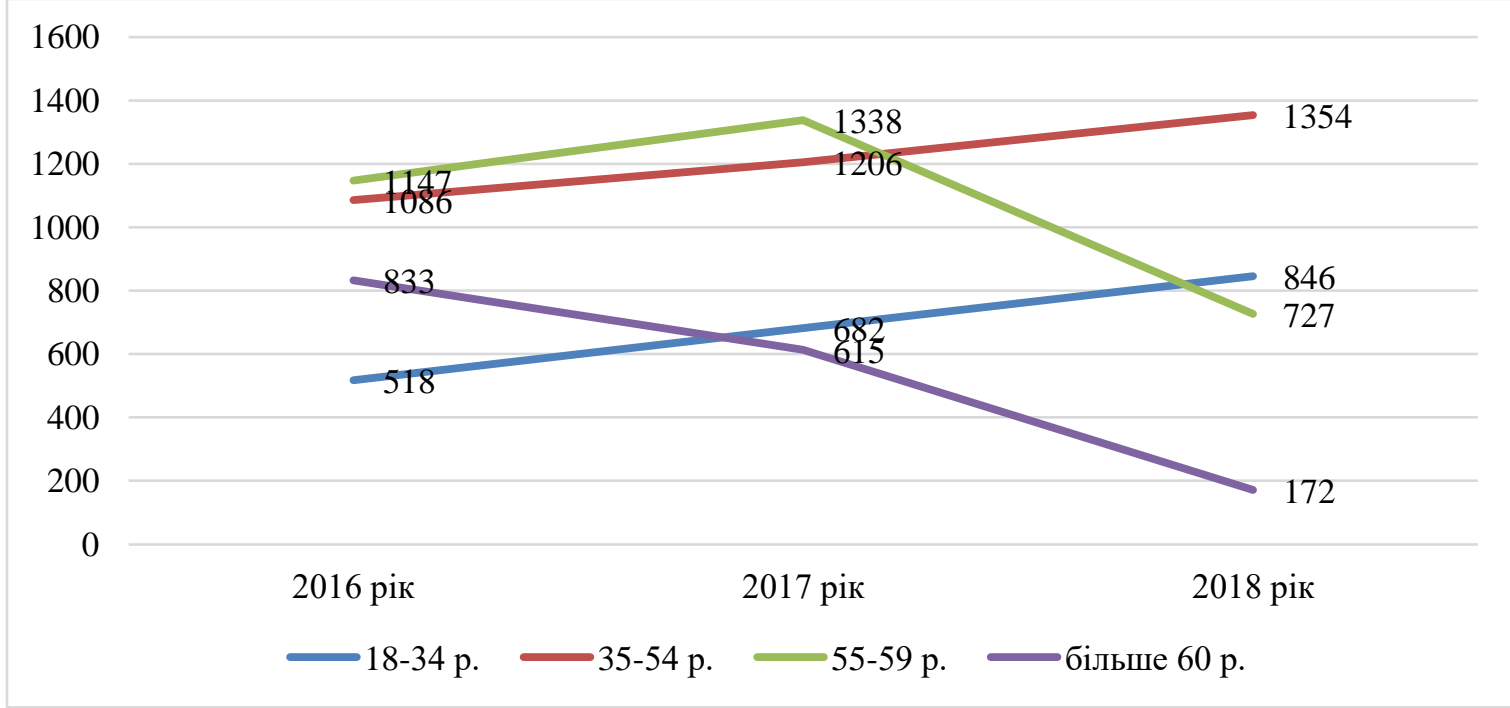

Рисунок 3 - Графік співвідношення працівників КП НВК «Іскра», за віковим критерієм у 2016-2018 pp. 
Через скорочення штату, нові вимоги до працівників та технічне оновлення виробництва кількість працівників передпенсійного (пенсійного) віку значно скоротилась: у 2016 році частка на підприємстві складала 32\%, а в 2018 році вона скоротилась до 23,4\%. Така ж ситуація і з працівниками віком від 60 років, на 2018 рік, порівняно із 2016 їх кількість скоротилася до 5,9\%, тобто зменшилась за 3 роки на 17,4 $\%$.

Отже, процес скорочення кадрів, погіршення економічної зацікавленості персоналу у роботі створює передумови негативних, конфліктних ситуацій на КП НВК «Іскра». Будь-який конфлікт, як правило, має сильний деструктивний заряд. Стихійний розвиток конфлікту дуже часто призводить до порушення нормального функціонування організації. Він зазвичай супроводжується потужними негативними емоціями, які сторони відчувають по відношенню один до одного. Ці емоції перешкоджають пошуку раціонального виходу і формують образ ворога, якого треба в що б те не стало знищити [4].

Для проведення дослідження конфліктних ситуацій в колективі відділу кадрів КП НВК «Іскра» була застосована методика діагностики схильності особистості до конфліктної поведінки К. Томаса [5]. Відділ кадрів складається з 18 осіб, з котрих 17 жінок і 1 чоловік. У всіх працівників відділу кадрів профільна освіта. Кожні 3 роки працівники проходять навчання. Періодично їх направляють на курси та семінари для підвищення рівня знань кадрової справи, а також створенню навичок у роботі 3 програмним забезпеченням. Адже відділ кадрів працює 3 понад 5 програмами, включаючи IC-ПРО (аналог 1C), meDoc, внутрішній електронний документообіг та інші. Віковий склад членів колективу- від 27 до 59 років. Для опису типів поведінки людей у конфліктних ситуаціях К. Томас запропонував двовимірну модель регулювання конфліктів, основні виміри в якій — кооперація (пов'язана з увагою людини до інтересів інших людей, які втягнені в конфлікт) і напористість (для якої характерний акцент на захисті власних інтересів). Відповідно до цих вимірів К. Томас виділяє такі способи регулювання конфліктів:

1) змагання (конкуренція) як прагнення досягти свого на шкоду іншому;

2) пристосування як протилежність суперництва, жертвування власними інтересами заради інших;

3) компроміс;

4) уникнення, коли немає як прагнення до кооперації, так i тенденції до досягнення власних цілей;

5) співпраця, коли учасники конфлікту приходять до ситуації, що повністю задовольняє інтереси обох сторін [6].

На думку К. Томаса, у разі уникнення конфлікту жодна зі сторін не досягає успіху. За таких форм поведінки, як конкуренція, пристосування та компроміс або один 3 учасників виявляється у виграші, а інший програє, або вони обидва програють, оскільки йдуть на компромісні поступки. І тільки в ситуації співпраці обидві сторони виявляються у виграші.

У результаті проведеного дослідження персоналу відділу кадрів було встановлено, що у даному колективі переважає тактика співпраці (табл. 2). Також було встановлено, що співробітники використовують у своїй діяльності практично всі стратегії поведінки. Але найбільшу кількість балів припадає на тактику співпраці та компромісу, тактика пристосування - 4.78 балів, і найменша кількість балів припадає на тактикууникнення-4,72 балів, та суперництва $-4,61$ балів. В колективі -суперництво, працівники не хочуть уникати конфлікт, погано пристосовуються до нових умов та 
нововведень. Співпраця та досягнення компромісу - нижче середнього. Враховуючи результати тесту, можна зробити висновок, що конфліктологічна ситуація у колективі відділу кадрів КП НВК «Іскра» - середня.

Таблиця 2

Результати діагностики за методикою К. Томаса [5]

\begin{tabular}{|c|c|c|c|c|c|}
\hline $\begin{array}{c}\text { № } \\
\text { співробітника }\end{array}$ & Пристосування & Уникнення & Компроміс & Співпраця & Суперництво \\
\hline 1 & 0 & 5 & 4 & 8 & 9 \\
\hline 2 & 1 & 3 & 8 & 9 & 7 \\
\hline 3 & 10 & 1 & 6 & 5 & 6 \\
\hline 4 & 4 & 6 & 8 & 10 & 4 \\
\hline 5 & 1 & 7 & 4 & 10 & 10 \\
\hline 6 & 2 & 6 & 3 & 9 & 8 \\
\hline 7 & 5 & 2 & 5 & 8 & 9 \\
\hline 8 & 10 & 1 & 4 & 5 & 5 \\
\hline 9 & 1 & 6 & 6 & 10 & 7 \\
\hline 10 & 4 & 4 & 2 & 2 & 5 \\
\hline 11 & 5 & 6 & 4 & 10 & 3 \\
\hline 12 & 5 & 4 & 4 & 3 & 5 \\
\hline 13 & 6 & 7 & 7 & 3 & 3 \\
\hline 14 & 6 & 6 & 4 & 6 & 4 \\
\hline 15 & 8 & 8 & 5 & 4 & 1 \\
\hline 16 & 3 & 4 & 9 & 7 & 6 \\
\hline 17 & 8 & 4 & 1 & 6 & 7 \\
\hline 18 & 6 & 5 & 4 & 2 & 4,61 \\
\hline Середнє & 4,78 & 4,72 & 4,88 & 6,5 & \\
\hline значення & & & & & \\
\hline
\end{tabular}

Переважають наступні проблеми: відсутність прагнення до кооперації та пасивність у відстоюванні своїх прав. Перенесення відповідальності за розв'язання проблеми на інших спрацьовує в ситуаціях, коли напруженість конфлікту досить висока і необхідно ії послабити; якщо рішення настільки незначні, що не слід витрачати сили на їхню зміну.

У відділі кадрів КП НВК «Іскра» на середньому рівні розвинена участь у розв'язанні конфлікту з відстоюванням як своїх інтересів, так і інтересів партнерів. Спільне обговорення проблем та потреб сторін спрацьовує в ситуаціях, де рішення $\epsilon$ важливим для обох сторін; якщо стосунки з партнерами довготривалі й корисні; якщо $\epsilon$ час і можливість попрацювати над подальшим розв'язанням складної ситуації; якщо бажання обох сторін збігаються; якщо між партнерами є статусна рівновага (стиль співпраці). Здатність поступитися своїми інтересами з обох сторін, що беруть участь у конфлікті. Нижче середнього проявлене прагнення прийняти рішення, що задовольняє обидві сторони, спрацьовує в ситуаціях, якщо ці сторони мають однакову владу, але протилежні інтереси; якщо необхідно виграти час і робітника задовольняє часткове рішення; якщо рішення потрібно прийняти швидко, тому що це найбільш економний і ефективний шлях; інші підходи до розв'язання проблеми видаються неефективними; $\epsilon$ бажання зберегти стосунки з протилежною стороною (стиль компромісу).

Отже, аналіз свідчить, що соціально-психологічний клімат на КП НВК «Іскра» 
спокійний, врівноважений, дещо негативний. Переважають песимістичні настрої, суперництво в колективі, робітники погано пристосовуються до нововведень, майже не уникають конфліктів, рідко йдуть на компроміс, але співпрацюють один з одним. Один одним працівники не задоволені, що робочий день проходить у нейтральних контактах та спілкуванні. Домінує діловий тон взаємовідносин. Конфлікти, якщо виникають, розв'язуються, але іноді виникає соціально-психологічна напруга та втрата інтересу до діяльності та взаємодії. При виникненні конфліктної ситуації найкращим варіантом поведінки в конфлікті співробітники віддають перевагу уникненню рішень.

Висновки 3 проведеного дослідження. Аналіз інформаційно-аналітичної інформації щодо управління конфліктами ситуаціями на КП НВК «Іскра» засвідчує, що на сьогоднішній день відсутня ефективна інформаційна система, як мала змогу врегулювати проблеми на підприємстві. Конфлікти часто породжуються нестатками i прихованими бажаннями, які не задовольняються менеджментом підприємства та політикою держави, зокрема. Головною передумовою існування конфліктів в сучасних кризових умовах є невпевненість персоналу (більше 90\% досліджуваних працівників відділу кадрів КП НВК «Іскра» - жінки) у професійному майбутньому в даній організації.

\section{СПИСОК ВИКОРИСТАНИХ ДЖЕРЕЛ}

1. Яхно Т. П., Куревіна І. О. Конфліктологія та теорія переговорів. навч. посіб. Київ: Центр учбової літератури, 2012. 168 с.

2. Пірен М. І. Конфліктологія: Підручник. Київ : МАУП, 2003. 360 с.

3. КП НВК «Іскра». URL: https://www.iskra.zp.ua/index.php?lang=ua (дата звернення: 02.02.2020).

4. Сугестивні технології маніпулятивного впливу: навч. посіб. / [В.М.Пет.рик, М.М. Присяжнюк, Л.Ф. Компанцева, Є.Д.Скулиш, О.Д.Бойко, В.В.Остроухов]; за заг. .ред. Є.Д.Скулиша. 2-ге вид. Київ: ВІПОЛ, 2011. 248 с.

5. Діагностика схильності до конфліктної поведінки. Методика К.Томаса. URL: https://vseosvita.ua/library/diagnostika-shilnosti-do-konfliktnoi-povedinki-metodika-ktomasa121591.html (дата звернення: 20.02.2020).

6. Нагаєв В. М. Конфліктологія: курс лекцій (модульний варіант): Навчальний посібник. Київ: Ц ЦУЛ, $2004 . \quad 198 \quad$ c. http://dspace.knau.kharkov.ua/jspui/bitstream/123456789/1077/1/\%D0\%9A\%D0\%BE\%D0\% BD\%D1\%84\%D0\%BB\%D0\%B8\%D0\%BA\%D1\%82\%D0\%BE\%D0\%BB._\%D0\%9F\%D0\% 94\%D0\% A4.PDF(дата звернення: 30.01.2020). 